\title{
Analisis Potensi Kelongsoran Pada Ruas Jalan Raya Pangalengan Menggunakan Sistem Informasi Geografis
}

\author{
(Analysis of Potential Landslide in the Pangalengan Road Using Geographic
} Information Systems)

\author{
Muhamad Raffi Rahman', Yuli Suharnoto', dan Heriansyah Putra ${ }^{1 *}$ \\ ${ }^{1}$ Departemen Teknik Sipil dan Lingkungan, Fakultas Teknologi Pertanian, Institut Pertanian Bogor. \\ Jl. Raya Dramaga, Kampus IPB Dramaga, PO BOX 220, Bogor, Jawa Barat Indonesia \\ *Penulis Korespondensi: heriansyahptr@app.ipb.ac.id
}

\begin{abstract}
Indonesian National Board for Disaster Management (BNPB) claimed the landslide incident on 5 May 2015 in Pangalengan District caused gas pipelines owned by PT. Geothermal Star Energy exploded, 9 people died, 154 displaced and 10 houses buried. Based on the facts, it is necessary to make an effort to reduce the risk of landslides by utilizing satellite imagery. The purpose of this study was to identify potential landslides on the Pangalengan highway and make recommendations mitigation actions for the local government. The method used was using 2 estimation system models made by the Directorate of Volcanology and Geological Disaster Mitigation in 2004 and 2005. The result of the DVMBG 2004 showed the very high classification had a percentage of $97.24 \%$ and the DVMBG 2005 result showed the high classification reached $53.26 \%$ and the very high classification reached 53.26\%. The potential for landslides on the Pangalengan road is $98.37 \%$. Recommended mitigation actions were cutting slopes or making soil retaining walls or drainage channel planning.
\end{abstract}

Keywords: DVMBG, landslide disaster, mitigation actions.

\section{PENDAHULUAN}

Pada umumnya bencana longsor terjadi akibat adanya pergerakan tanah yang kehilangan daya dukungnya yang disebabkan oleh curah hujan yang tinggi dan keadaan lereng yang curam (Guzzeti et al 2004; Hafidz et al, 2019). Smaalen (1980) dalam Indrawahyuni et al (2009) menyampaikan bahwa kemampuan tanah dalam meloloskan air berbeda-beda, tergantung pada permeabilitas jenis tanah. Pada ruang-ruang kosong yang terdapat diantara butiran tanah, terdapat tekanan air pori yang muncul karena adanya aliran air diantara butiran tanah tersebut (Putra et al., 2017). Peningkatan kandungan air dalam tanah dapat menurunkan kepadatan dan kekuatan geser (kohesi dan sudut geser) antar partikel tanah sehingga stabilitas menurun (Putra et al., 2017; Hafidz et al, 2019). Salah satu daerah yang memiliki rekam jejak bencana longsor terdapat pada ruas jalan raya Pangalengan, Kecamatan Pangalengan, Kabupaten Bandung.

Badan Nasional Penanggulangan Bencana (BNPB) menyebutkan bahwa kejadian longsor tanggal 5 Mei 2015 di 
JSIL | Rahman dkk. : Analisis Kelongsaran Pada Ruas Jalan Raya Pangalengan Menggunakan Sistem Infarmasi Geografis

Kecamatan Pangalengan menyebabkan kerusakan yang besar. Longsor yang terjadi seluas $0.5 \mathrm{Km}^{2}$ yang menyebabkan pipa gas PT. Geothermal Star Energy meledak. Korban jiwa dinyatakan 9 orang meninggal, yang ditemukan 7 orang, 4 orang luka berat, sebanyak 154 orang mengungsi, 10 rumah tertimbun dan terputusnya pipa aliran uap panas bumi Star Energy antara kampung Cibitung dan Separator Area (BNPB 2015). Berdasarkan fakta yang ada, maka upaya pengurangan resiko bencana longsor di Kecamatan Pangalengan sangat perlu dilakukan. Upaya untuk mendukung hal tersebut yaitu dengan mengaanalisis potensi rawan longsor di Kecamatan Pangalengan dengan memanfaatkan citra satelit.

Tujuan penelitian ini yaitu mengidentifikasi potensi bencana longsor pada ruas jalan raya Pangalengan, memberikan informasi kejadian longsor 2 tahun terakhir pada ruas jalan raya Pangalengan, dan menyusun rekomendasi bagi pemerintah setempat sebagai upaya mitigasi longsor.

\section{METODOLOGI}

Penelitian dilakukan dari bulan April hingga bulan Juli 2019 pada ruas jalan raya Pangalengan, Kec. Pangalengan, Kab. Bandung. Peralatan yang digunakan yaitu GPS. Bahan yang digunakan dalam penelitian ini adalah citra DEM NAS Kabupaten Bandung 2018, citra Landsat 8 P.125/R.65 tahun 2018, data curah hujan Kabupaten Bandung, Peta geologi digital Kabupaten Bandung, Peta jenis tanah Kabupaten Bandung, dan jumlah penduduk Kecamatan Pangalengan. Juga dibutuhkan komputer yang dilengkapi dengan software
Microsoft Word, Microsoft Excel, Google Earth dan ArcGIS 10.4.1.

Penelitian diawali dengan pengumpulan data sekunder meliputi data curah hujan, peta geologi digital, peta jenis tanah, peta tutupan lahan, peta kemiringan lereng, dan data kepadatan penduduk Kecamatan Pangalengan. Kemudian dilakukan analisis menggunakan sistem model pendugaan yang dibuat oleh Direktorat Vulkanologi dan Mitigasi Bencana Geologi (DVMBG) tahun 2004 dan 2005 menggunakan persamaan (1) dan (2). Adapun parameter skoring peniliaian potensi longsor disajikan pada Tabel 1-7.

$$
\begin{array}{r}
\text { Skor }=(30 \% \times \mathrm{A})+(20 \% \times \mathrm{B})+(20 \% \times \\
\mathrm{C})+(15 \% \times \mathrm{D})+(15 \% \times \mathrm{E}) \ldots \ldots(1)
\end{array}
$$

Sumber: DVMBG (2004)

$$
\begin{array}{r}
\text { Skor }=(30 \% \times \mathrm{A})+(25 \% \times \mathrm{F})+(20 \% \times \\
\mathrm{D})+(25 \% \times \mathrm{E}) \ldots \ldots \ldots \ldots \ldots \ldots(2)
\end{array}
$$

Sumber: DVMBG (2005)

Tabel 1 Parameter Longsor

\begin{tabular}{clc}
\hline No. & \multicolumn{1}{c}{ Parameter } & Kode \\
\hline 1 & Curah Hujan & A \\
2 & Geologi & B \\
3 & Jenis Tanah & C \\
4 & Tutupan Lahan & D \\
5 & Kemiringan Lereng & E \\
6 & Kepadatan Penduduk & F \\
\hline
\end{tabular}

Tabel 2 Parameter skor curah hujan

\begin{tabular}{ccc}
$(30 \%)$ & & \\
\hline Parameter & Besaran $(\mathrm{mm})$ & Skor \\
\hline & $<1000$ & 1 \\
& $1000-2000$ & 2 \\
CH Tahunan & $2000-2500$ & 3 \\
& $2500-3000$ & 4 \\
& $>3000$ & 5 \\
\hline
\end{tabular}

Sumber: DVMBG (2004) 
Tabel 3 Parameter skor geologi (20\%)

\begin{tabular}{|c|c|c|}
\hline Parameter & Besaran & Skor \\
\hline \multirow{4}{*}{ Geologi } & Endapan Aluvial, Batuan beku dengan pelapukan rendah & 1 \\
\hline & Batu gamping, dengan soil la[pukan tipis, berada pada daerah skruktur geologi & 2 \\
\hline & & \\
\hline & $\begin{array}{l}\text { Batuan ubahan, memiliki soil tebal, terdapat napal, lempung, berada di jalur } \\
\text { struktur geologi, meiliki banyak rekahan }\end{array}$ & 3 \\
\hline \multicolumn{3}{|c|}{ Sumber: LPBI-NU (2017) } \\
\hline \multicolumn{3}{|c|}{ Tabel 4 Parameter skor tutupan lahan (15\%) } \\
\hline Parameter & Besaran & Skor \\
\hline \multirow{5}{*}{ Tutupan Lahan } & Hutan/vegetasi lebat dan badan air & 1 \\
\hline & Kebun dan campuran semak belukar & 2 \\
\hline & Perkebunan dan sawah irigasi & 3 \\
\hline & Kawasan industri dan pemukiman & 4 \\
\hline & Lahan-lahan kosong & 5 \\
\hline
\end{tabular}

Sumber: DVMBG (2004)

Tabel 5 Parameter skor jenis tanah (20\%)

\begin{tabular}{clc}
\hline Parameter & \multicolumn{1}{c}{ Besaran } & Skor \\
\hline \multirow{5}{*}{ Janeis tanah } & Aluvial & 1 \\
& Asosiasi latosol coklat latosol kekuningan, asosiasi latosol merah latosol coklat & 2 \\
& kemerahan dan asosiasi latosol coklat latosol kemerahan & Asosiasi latosol coklat regosol \\
& $\begin{array}{l}\text { Andosol, podsolik merah kekuningan, asosiasi andosol regosol, podsolik } \\
\text { kekuningan dan podsolik merah }\end{array}$ & 3 \\
& Regosol & 4 \\
\hline
\end{tabular}

Sumber: PUSLITANAK (1976)

Tabel 6 Parameter skor kemiringan lereng (15\%)

\begin{tabular}{lll}
\hline Parameter & Besaran $(\%)$ & Skor \\
\hline & $<8$ & 1 \\
Kemiringan & $8-15$ & 2 \\
lereng & $15-25$ & 3 \\
& $25-45$ & 4 \\
& $>45$ & 5 \\
\hline
\end{tabular}

Sumber: DVMBG (2004
Tabel 7 Parameter kepadatan penduduk (25\%)

\begin{tabular}{lll}
\hline Parameter & Besaran & Skor \\
\hline \multirow{3}{*}{ Kepadatan } & $<49$ & 1 \\
Penduduk & $50-249$ & 2 \\
& $250-399$ & 3 \\
\cline { 2 - 3 } & $>400$ & 4 \\
\hline
\end{tabular}

$\overline{\text { Sumber: Undang-undang Nomor 56/PRP (1960) }}$ 
JSIL | Rahman dkk. : Analisis Kelongsaran Pada Ruas Jalan Raya Pangalengan Menggunakan Sistem Infarmasi Geografis

Setelah dilakukan analisis model pendugaan bencana longsor menggunakan sistem DVMBG 2004 dan 2005 diperoleh peta rawan longsor Kecamatan Pangalengan. Kemudian di input data kejadian longsor di Kecamatan Pangalengan dari tahun 2015 sampai tahun 2019 untuk digunakan sebagai validasi peta longsor. Setelah analisis selesai dilakukan, kemudian dilakukan ground check di lapangan untuk memperoleh data rekomendasi potensi rawan longsor pada ruas jalan raya Pangalengan.

\section{HASIL DAN PEMBAHASAN}

\section{Parameter Analisis Longsor}

\section{DEM Nasional}

Data DEM Nasional dibangun dari beberapa sumber data meliputi IFSAR (resolusi 5m), TERRASAR-X (resolusi 5m) dan ALOS PALSAR (resolisi $11.25 \mathrm{~m})$ dengan menambahkan data masspoint hasil stereo-plotting. Hasil analisis data DEM Nasional disajikan pada Tabel 8.

Tabel 8 Hasil analisis kemiringan lereng Kecamatan Pangalengan

\begin{tabular}{ccrr}
\hline & & & \multicolumn{2}{c}{$\begin{array}{c}\text { Persentase } \\
(\%)\end{array}$} \\
\hline 1 & $<8 \%$ & 332.03 & 1.52 \\
2 & $8-15 \%$ & 9127.84 & 41.75 \\
3 & $15-25 \%$ & 6177.48 & 28.25 \\
4 & $25-45 \%$ & 5235.52 & 23.94 \\
5 & $>45 \%$ & 982.48 & 4.49 \\
\hline
\end{tabular}

Kemiringan lereng di Kecamatan Pangalengan di dominasi oleh kemiringan lereng $8-15 \%$ dengan persentase $41.75 \%$ seluas 9127.84 ha, $15-25 \%$ sebesar $28.25 \%$ dengan luas 6177.48 ha, dan kemiringan $25-45 \%$ sebesar $23.94 \%$ dengan luas $5235.52 \mathrm{ha}$. Untuk kemiringan $<8 \%$ memiliki persentase $1.52 \%$ dengan luas lahan 332.03 ha dan kemiringan lereng $>45 \%$ memiliki persentase $4.49 \%$ dengan luas lahan sebesar $982.48 \%$. Peta kemiringan lereng Kecamatan Pangalengan disajikan pada Gambar 1.

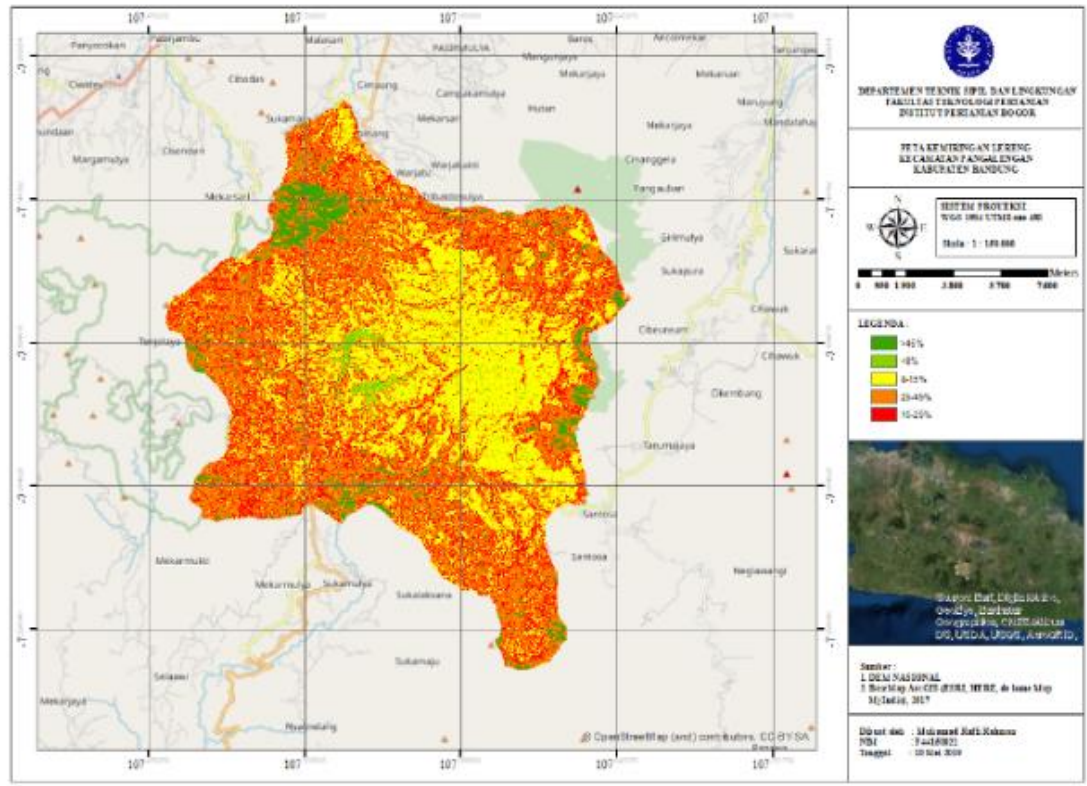

Gambar 1 Peta Kemiringan Lereng Kecamatan Pangalengan 


\section{Citra Landsat 8 P.122/R.65 OLI/TIRS C1 Level 1}

Pengolahan citra Landsat 8 TIRS/OLI C1 Level 1 menggunakan metode supervised classification. Supervised classification merupakan salah satu cara interpretasi citra dengan menggunakan spectral signature yang diperoleh dari training samples untuk mengklasifikasikan pixel ke dalam suatu kelompok (Al-doski et al 2013). Hasil analisis citra landsat 8 disajikan pada Tabel 9.

Tabel 9 Hasil analisis Citra Landsat 8 OLI/TIRS C1 Level 1

\begin{tabular}{clrr}
\hline No & Tutupan Lahan & Luas (ha) & $\begin{array}{r}\text { Persentase } \\
(\%)\end{array}$ \\
\hline 1 & Badan Air & 150.76 & 0.69 \\
2 & Hutan Lebat & 1188.05 & 5.45 \\
3 & Kebun & 6085.89 & 27.92 \\
4 & Lahan kosong & 786.71 & 3.61 \\
5 & Pemukiman & 2258.79 & 10.36 \\
6 & Perkebunan & 11326.37 & 51.96 \\
\hline & Berdasarkan & hasil analisis citra
\end{tabular}

landsat 8 perkebunan merupakan penggunaan lahan yang dominan yang berada di Kecamatan Pangalengan dengan persentase sebesar $51.91 \%$ dengan luas lahan sebesar 11326.37 ha. Kebun memiliki persentase sebesar $27.92 \%$ dengan total luas lahan sebesar 6085.89 ha. pemukiman memiliki persentase $10.36 \%$ dengan luas lahan 2258.79 ha, lahan kosong memiliki persentase $0.69 \%$ dengan luas lahan 786.71, Badan air memiliki persentase $0.69 \%$ dengan luas 150.76 ha dan hutan lebar $5.45 \%$ dengan luas lahan 1188.05 ha. Adapun peta tutupan lahan Kecamatan Pangalengan disajikan pada Gambar 2.

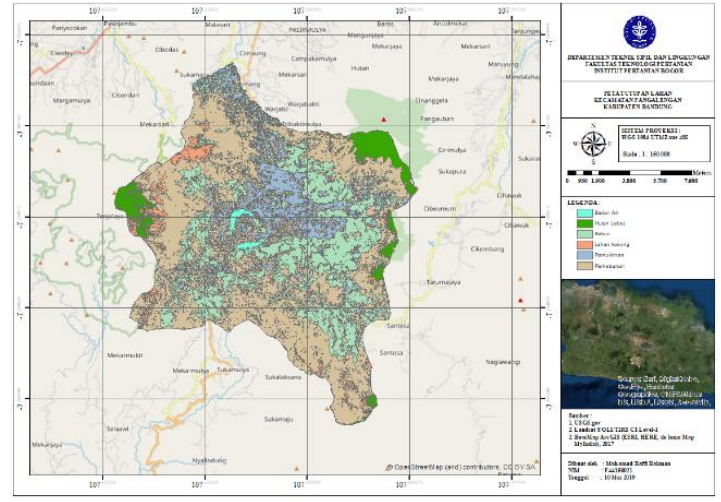

Gambar 2 Peta Tutupan Lahan Kecamatan Pangalengan

\section{Curah Hujan}

Menurut penelitian yang dilakukan oleh Simon dan Larsen (1993) di Puerto Rico meyebutkan bahwa Curah hujan 100$200 \mathrm{~mm}$ per hari, Sekitar $14 \mathrm{~mm} / \mathrm{jam}$ atau 2-3 mm/ jam selama 100 jam dapat menyebabkan tanah longsor. Dan Penelitian yang dilakukan oleh Guzzetti et al (2004) menyampaikan bahwa wilayah Liguria Barat Italia mengalami curah hujan yang panjang dan intens, dengan nilai kumulatif $1000 \mathrm{~mm}$ dalam 45 hari. Peristiwa dengan intensitas hujan yang tinggi dan intens menyebabkan banjir dan terjadinya longsor sebanyak 1204 titik untuk total luas tanah longsor seluas 1.6 $\mathrm{Km}^{2}$. Data stasiun yang digunakan pada penelitian ini diantaranya yaitu stasiun Cileunca, Cipanas, Margamukti, dan stasiun Kertasari. Pengolahan data curah hujan ini menggunakan metode Polygon Thiessen. Hasil pengolahan Polygon Thiessen dapat dilihat pada Tabel 10.

Curah hujan di Kecamatan Pangalengan dan sekitarnya sangat tinggi. Data stasiun curah hujan yang memiliki curah hujan yang paling tinggi yaitu stasiun Kertamanah, yaitu mencapai 4278 $\mathrm{mm} /$ tahun dengan sebaran 3583.10 ha. 
JSIL | Rahman dkk. : Analisis Kelongsaran Pada Ruas Jalan Raya Pangalengan Menggunakan Sistem Infarmasi Geografis

Tabel 10 Hasil analisis data curah hujan

\begin{tabular}{|c|c|c|c|c|c|}
\hline \multirow{2}{*}{ No } & \multirow{2}{*}{$\begin{array}{l}\text { Stasiun Curah } \\
\text { hujan }\end{array}$} & \multicolumn{2}{|c|}{ Koordinat Stasiun $\left({ }^{\circ}\right)$} & \multirow{2}{*}{$\begin{array}{c}\mathrm{CH} \\
\text { (mm/tahun) }\end{array}$} & \multirow{2}{*}{ Luas (ha) } \\
\hline & & $\mathrm{X}$ & $\mathrm{Y}$ & & \\
\hline 1 & Cileunca & 107.550556 & -7.1933333 & 3152 & 906,78 \\
\hline 2 & Cipanas & 107.601156 & -7.1876889 & 3433 & 10826.10 \\
\hline 3 & Kertamanah & 107.610633 & -7.1897972 & 4278 & 3583.06 \\
\hline 4 & Kertasari & 107.692042 & -7.2776361 & 4061 & 6351.16 \\
\hline
\end{tabular}

Adapun peta hasil pengolahan curah hujan dapat dilihat pada Gambar 3.



Gambar 3 Peta Curah Hujan Kecamatan Pangalengan

\section{Geologi}

Menurut proses terbentuknya batuan dibagi menjadi 3 jenis batuan yaitu batuan beku, batuan sedimen dan batuan metamorf. Batuan beku disebut dengan igneous rock, yang termasuk batuan beku adalah lava dan scoria (terak) (Doddy 1987). Hasil analisis batuan yang ada di Kecamatan Pangalengan disajikan pada Tabel 11. Kecamatan Pangalengan memiliki 6 jenis batuan dari hasil analisis geologi di Kecamatan Pangalengan. Dainataranya batuan gunung api muda dengan luas 481.91 ha dengan persentase $2.20 \%$

Batuan terobosan dengan luas 677.81 ha dengan persentase $3.10 \%$. Batugamping terumbu 3493.45 ha dengan persentase $15.98 \%$. Waringin-Bedil andesit seluas 1706.09 ha dengan persentase $7.80 \%$. Sedangkan batuan endapan efflata gununga api tua merupakan batuan yang mendominasi batuan yang ada di Kecamatan Pangalengan yaitu sebesar $70.76 \%$. Adapun peta geologi Kecamatan Pangalengan disajikan pada Gambar 4

Tabel 11 Hasil analisis geologi Kecamatan Pangalengan

\begin{tabular}{cllcc}
\hline No & Simbol & \multicolumn{1}{c}{ Geologi } & Luas (ha) & Persentase (\%) \\
\hline 1 & Qyw & Batuan gunung api Muda & 481.91 & 2.20 \\
2 & Q & Batuan Terobosan & 677.81 & 3.10 \\
3 & Q1 & Batugamping Terumbu & 3493.45 & 15.98 \\
4 & Qyg & Endapan Breksi \& Lahar Gunung Gede & 32.28 & 0.15 \\
5 & Qopu & Endapan efflata gunung api tua & 15467.6 & 70.76 \\
6 & Qwb & Waringin-Bedil Andesit & 1706,09 & 7.80 \\
\hline
\end{tabular}




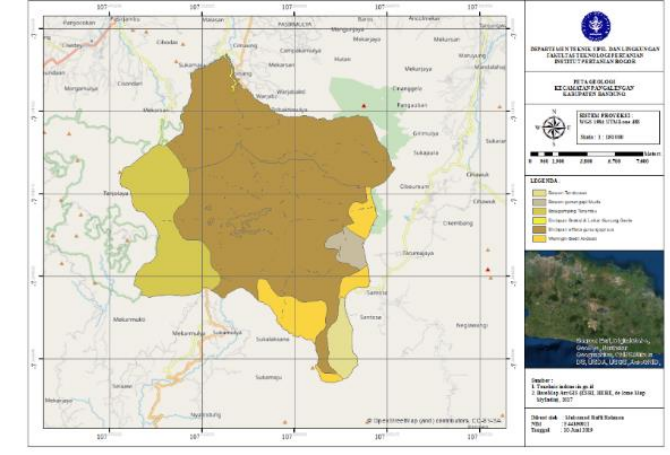

Gambar 4 Peta Geologi Kecamatan Pangalengan

\section{Jenis Tanah}

Jenis tanah di Kabupaten Bandung terdapat 7 klasifikasi tanah utama yaitu: regosol, andosol, grumusol, mediteran, podsolik merah-kekuningan dan podsolik merah kuning. Menurut teori Mohr (1910), kondisi keruntuhan suatu bahan terjadi akibat adanya kombinasi keadaan kritis dari tegangan normal dan tegangan geser. Menurut Santosa dkk (1998), Shear failur atau keruntuhan geser bukan disebabkan karena hancurnya butir butir tanah melainkan karena adanya gerak relatif antara butir butir tanah tersebut.

Tabel 12 Hasil analisis Jenis Tanah di Kecamatan Pangalengan

\begin{tabular}{clcc}
\hline No & Jenis Tanah & Luas (ha) & Persentase (\%) \\
\hline 1 & Andosol & 19721.117 & 90,24 \\
2 & Mediteran & 2132.625 & 9,76 \\
\hline
\end{tabular}

Kecamatan Pangalengan memiliki 2 jenis tanah yaitu tanah andosol dan jenis tanah mediteran. Jenis tanah andosol memiliki luas sebesar 19721.117 ha dengan persentase $90.24 \%$ dan jenis tanah mediteran seluas 2132.625 ha dengan persentase $9.76 \%$. Peta jenis tanah Kecamatan Pangalengan disajikan pada Gambar 5.

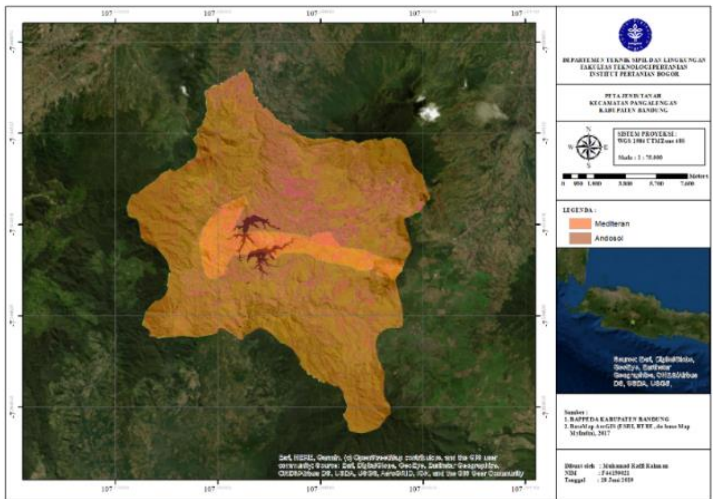

Gambar 5 Peta Jenis Tanah

Kecamatan Pangalengan

\section{Kepadatan Penduduk}

Kecamatan Pangalengan merupakan salah satu kecamatan besar yang ada di Kabupaten Bandung. Tercatat bahwa Kecamatan Pangalengan memilki 13 Desa yang memilki luas lahan yang cukup luas. Hasil analisis kepadatan penduduk di Kecamatan Pangalengan dapat dilihat pada Tabel 13. Adapun peta kepadatan penduduk disajikan pada Gambar 6.

Hasil tersebut menunjukkan bahwa Desa Pengalengan memiliki tingkat kepadatan penduduk yang paling tinggi diantara desa lainnya, kepadatan penduduk di Desa Pangalengan yaitu sebesar 36.41 org/ha dengan persentase $26.19 \%$. Menurut skor yang dikeluarkan oleh Undang-undang Nomor 56/PRP 1960 hasil persentase yang dihasilkan oleh Desa Pangalengan dapat di kategorikan pada kepadatan penduduk yang rendah karena $<40$ org/ha. 
JSIL | Rahman dkk. : Analisis Kelongsaran Pada Ruas Jalan Raya Pangalengan Menggunakan Sistem Infarmasi Geografis

Tabel 13 Hasil analisis kepadatan penduduk Kecamatan Pangalengan

\begin{tabular}{clcccc}
\hline No & Desa & Total Penduduk (org) & Luas (ha) & Kepadatan Penduduk/ha & Persentase $(\%)$ \\
\hline 1 & Wanasuka & 4616 & 4555.97 & 1.01 & 0.73 \\
2 & Banjarsari & 5961 & 2208.97 & 2.70 & 1.94 \\
3 & Margaluyu & 9212 & 860.2 & 10.71 & 7.70 \\
4 & Sukaluyu & 8909 & 1748.2 & 5.10 & 3.67 \\
5 & Warnasari & 8723 & 2354.12 & 3.71 & 2.67 \\
6 & Pulosari & 10905 & 5118.15 & 2.13 & 1.53 \\
7 & Margamekar & 8926 & 817.99 & 10.91 & 7.85 \\
8 & Sukamanah & 20356 & 668.04 & 30.47 & 2.92 \\
9 & Margamukti & 17146 & 2613.05 & 6.56 & 2.72 \\
10 & Pangalengan & 21482 & 589.95 & 36.41 & 9.87 \\
11 & Margamulya & 17752 & 1294.14 & 13.72 & 9.30 \\
12 & Tribakti mulya & 5817 & 449.91 & 12.93 & 1.92 \\
13 & Lamajang & 10744 & 4016.1 & 2.68 & \\
\hline
\end{tabular}

Sumber: BPS (2017

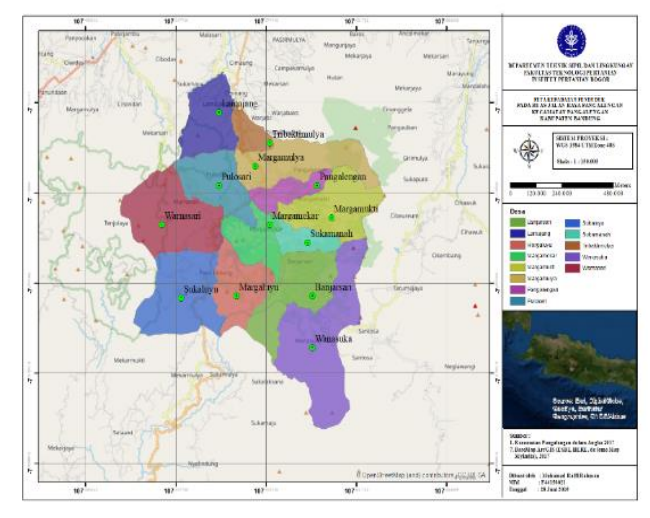

Gambar 6 Peta Kepadatan Penduduk Kecamatan Pangalengan

\section{Model Pendugaan Bencana Lngsor DVMBG 2004}

Parameter longsor yang mengacu pada model pendugaan bencana longsor oleh DVMBG 2004 ada 5 paremeter. Diantaranya curah hujan dengan persentase $30 \%$, kemiringan lereng $15 \%$, geologi $20 \%$, faktor jenis tanah $20 \%$, dan tutupan lahan $15 \%$. Hasil analisis potensi rawan longsor disajikan pada Tabel 14.
Tabel 14 Hasil Analisis potensi rawan longsor menggunakan DVMBG 2004

\begin{tabular}{cccc}
\hline No & Klasifikasi & Luas (ha) & $\begin{array}{c}\text { Persentase } \\
(\%)\end{array}$ \\
\hline 1 & Sangat Rendah & 64.97 & 0.30 \\
2 & Rendah & 6.23 & 0.03 \\
3 & Sedang & 14.48 & 0.07 \\
4 & Tinggi & 520.59 & 2.37 \\
5 & Sangat Tinggi & 21324.39 & 97.24 \\
\hline
\end{tabular}

Sumber: BPS 2017

Hasil analisis potensi rawan longsor di Kecamatan Pangalengan menurut model pendugaan DVMBG 2004 menunjukkan bahwa klasifikasi sangat tinggi mencapai angka $97.24 \%$ dan dapat dikatakan bahwa hampir seluruh daerah di Kecamatan Pangalengan berpotensi longsor. Validasi peta longsor dilakukan dengan menggunakan data kejadian longsor 5 tahun terakhir yang terjadi di Kecamatan Pangalengan. Adapun peta longsor Kecamatan Pangalengan menurut moedel pendugaan DVMBG 2004 disajikan pada Gambar 7. 


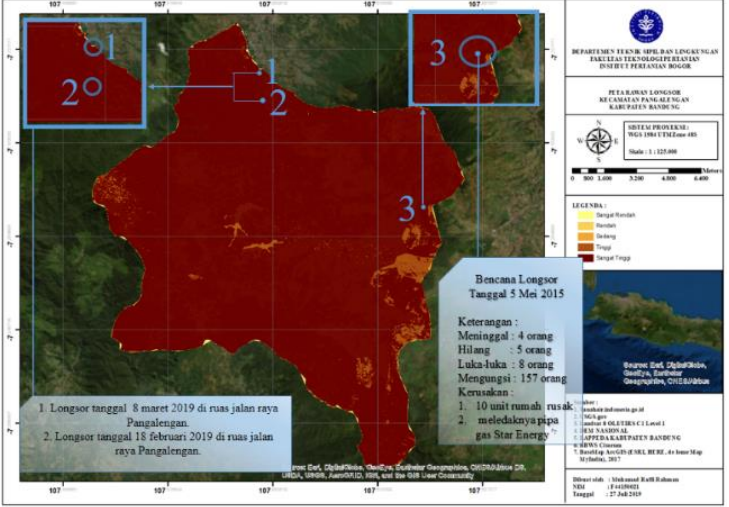

Gambar 7 Peta Kelongsoran Kecamatan Pangalengan menggunakan model pendugaan longsor DVMBG 2004

\section{Model Pendugaan Bencana Longsor DVMBG 2005}

Parameter model pendugaan bencana longsor yang dikeluarkan oleh Direktorat Vulkanologi dan Mitigasi Bencana Geologi pada tahun 2005 terdapat 4 parameter. Diantaranya curah hujan dengan persentase 30\%, kepadatan penduduk $25 \%$, penggunaan lahan $20 \%$, dan kemiringan lereng $25 \%$. Hasil analisis disajikan pada Tabel 15 .

Tabel 15 Hasil analisis potensi longsor menggunakan DVMBG 2005

\begin{tabular}{rlrr}
\hline No & Klasifikasi & \multicolumn{1}{c}{$\begin{array}{c}\text { Luas } \\
\text { (ha) }\end{array}$} & \multicolumn{1}{c}{$\begin{array}{c}\text { Persentase } \\
(\%)\end{array}$} \\
\hline 1 & Sangat Rendah & 8.62 & 0.04 \\
2 & Rendah & 9.32 & 0.04 \\
3 & Sedang & 489.51 & 2.24 \\
4 & Tinggi & 9717.8 & 44.42 \\
5 & Sangat Tinggi & 11652.93 & 53.26 \\
\hline
\end{tabular}

Hasil analisis potensi longsor menggunakan model pendugaan bencana longsor DVMBG 2005 menunjukkan bahwa klasifikasi tinggi dan sangat tinggi mendominasi potensi bencana longsor di Kecamatan Pangalengan. Untuk persentase klasifikasi tinggi mencapai
$44.42 \%$ dan klasifikasi sangat tinggi mencapai $53.26 \%$. Validasi peta longsor dilakukan dengan menggunakan data kejadian longsor 5 tahun terakhir yang terjadi di Kecamatan Pangalengan. Hasil input data menunjukkan bahwa kejadian longsor yang terjadi di Kecamatan Pangalengan berada pada klasifikasi sangat tinggi. Hal ini menunjukkan bahwa model pendugaan bencana longsor DVMBG 2004 dan 2005 tervalidasi dan dapat digunakan sebagai acuan tindakan mitigasi bencana longsor. Adapun peta longsor Kecamatan Pangalengan menurut DVMBG 2005 disajikan pada Gambar 8.

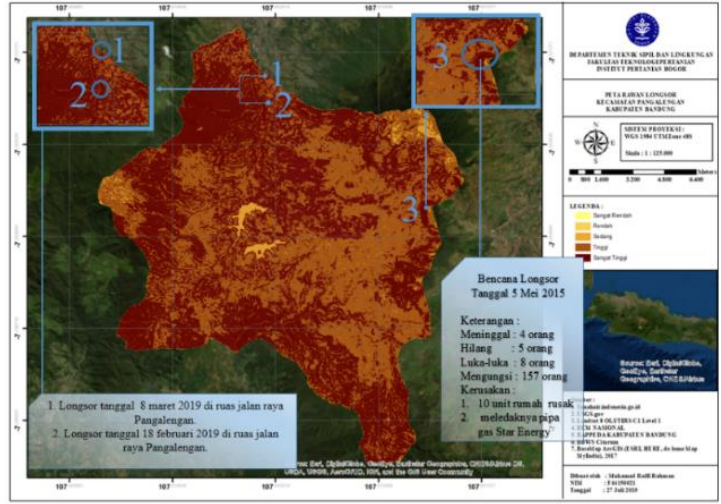

Gambar 8 Peta longsor Kecamatan Pangalengan menggunakan model pendugaan longsor DVMBG 2005

\section{Analisis Potensi Longsor Pada Ruas Jalan Raya Pangalengan}

Hasil analisis potensi rawan longsor pada ruas jalan raya Pangalengan disajikan pada Tabel 16. Hasil analisis menunjukkan bahwa potensi rawan longsor pada ruas jalan raya Pangalengan sangat tinggi. Tercatat untuk klasifikasi tinggi mencapai $44.267 \%$ dan klasifikasi sangat tinggi mencapai $55.70 \%$. peta longsor pada ruas jalan raya Pangalengan disajikan pada Gambar 9. Data rekapitulasi bencana longsor pada ruas jalan raya Pangalengan 
disajikan pada Tabel 17. Tercatat selama 2 tahun terakhir yaitu pada tahun 2018 dan 2019 telah terjadi longsor pada ruas jalan raya Pangalengan sebanyak 6 kali. Walaupun tidak ada korban jiwa dan kerusakan yang besar, namun hal ini tetap mengkhawatirkan jika tidak dilakukan tindakan mitigasi. Hasilnya menunjukkan bahwa kejadian longsor pada ruas jalan raya Pangalengan pada tahun 2018 dan 2019 berada pada klasifikasi sangat tinggi.

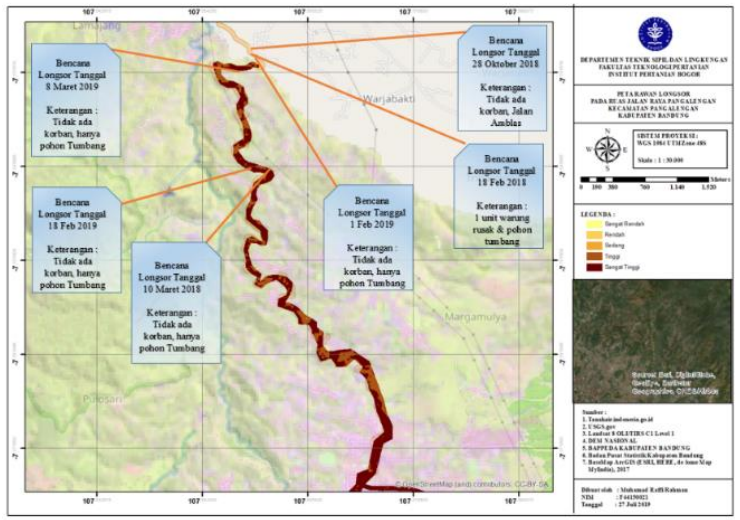

Gambar 9 Peta Longsor Pada Ruas Jalan Raya Pangalengan

Tabel 16 Hasil analisis potensi rawan longsor pada ruas jalan raya Pangalengan

\begin{tabular}{ccccc} 
No & Jalan & Klasifikasi & Luas (ha) & Persentase (\%) \\
\hline 1 & & Sangat Rendah & 0.01 & 0.00 \\
2 & Jalan Raya & Rendah & 0.07 & 0.01 \\
3 & Sangalengan & Sedang & 0.20 & 0.03 \\
4 & & Tinggi & 29,19 & 44.26 \\
5 & & Sangat Tinggi & 36.47 & 55.70 \\
\hline
\end{tabular}

Tabel 17 Kejadian longsor 2 tahun terakhir pada ruas jalan raya Pangalengan

\begin{tabular}{|c|c|c|c|c|c|}
\hline No & $\begin{array}{c}\text { Koordinat } \\
X\left({ }^{\circ}\right)\end{array}$ & $\begin{array}{c}\text { Koordinat } Y \\
\left({ }^{\circ}\right)\end{array}$ & $\begin{array}{l}\text { Kejadian } \\
\text { Longsor }\end{array}$ & Lokasi Longsor & Kerusakan \\
\hline 1 & 107.5588 & -7.128828 & $\begin{array}{l}19 \text { Februari } \\
2018\end{array}$ & $\begin{array}{l}\text { Jalan Pangalengan- } \\
\text { sukawening }\end{array}$ & $\begin{array}{l}\text { Pohon tumbang, } 1 \text { unit } \\
\text { warung rusak }\end{array}$ \\
\hline 2 & 107.142 & -7.141978 & 10 Maret 2018 & Tikungan S & Pohon tumbang \\
\hline 3 & 107.559 & -7.128128 & $\begin{array}{l}28 \text { Oktober } \\
2018\end{array}$ & $\begin{array}{l}\text { Jalan Pangalengan- } \\
\text { sukawening }\end{array}$ & Jalan Amblas \\
\hline 4 & 107.5581 & -7.128308 & $\begin{array}{l}1 \text { Februari } \\
2019\end{array}$ & $\begin{array}{l}\text { Jalan Pangalengan- } \\
\text { Cikalong }\end{array}$ & Pohon tumbang \\
\hline 5 & 107.5581 & -7.141133 & $\begin{array}{l}18 \text { Februari } \\
2019\end{array}$ & Tikungan $\mathrm{S}$ & Pohon tumbang \\
\hline 6 & 107.5583 & -7.131397 & 8 Maret 2019 & $\begin{array}{l}\text { Pangalengan- } \\
\text { Pulosari }\end{array}$ & Pohon tumbang \\
\hline
\end{tabular}

\section{Rekomendas Data Koordinat Tindakan Mitigasi Longsor}

Hasil akhir dari penelitian ini yaitu untuk memberikan rekomendasi koordinat mitigasi longsor pada ruas jalan raya Pangalengan kepada pemerintah setempat.
Setelah melakukan ground check dilapangan diperoleh koordinat lereng yang memiliki potensi longsor yang cukup tinggi, hal tersebut dibuktikan dengan beberapa koordinat yang sudah memiliki retakan-retakan pada lereng bahkan sudah ada longsoran yang terjadi. Koordinat 
rekomendasi pada ruas jalan raya Pangalengan disajikan pada Tabel 18. Adapun peta rekomendasi potensi terjadinya longsor pada ruas jalan raya Pangalengan disajikan pada Gambar 10.

Tabel 18 Koordinat rekomendasi tindakan mitigasi pada ruas jalan raya Pangalengan

\begin{tabular}{|c|c|c|c|}
\hline \multirow{2}{*}{ No } & \multirow{2}{*}{ Desa } & \multicolumn{2}{|c|}{ Koordinat Mitigasi } \\
\hline & & $X(0)$ & $Y(0)$ \\
\hline 1 & Tribaktimulya & $107^{\circ} 33^{\prime} 33.05^{\prime \prime E}$ & $7^{\circ} 7 ' 53.63 " \mathrm{~S}$ \\
\hline 2 & & $107^{\circ} 33^{\prime} 24.59^{\prime \prime} \mathrm{E}$ & $7^{\circ} 8^{\prime} 0.25 " \mathrm{~S}$ \\
\hline 3 & & $107^{\circ} 33^{\prime} 29.55^{\prime \prime} \mathrm{E}$ & $7^{\circ} 8^{\prime} 21.84^{\prime \prime S}$ \\
\hline 4 & & $107^{\circ} 33^{\prime} 41.38^{\prime \prime E}$ & $7^{\circ} 8^{\prime} 31.85^{\prime \prime S}$ \\
\hline 5 & & $107^{\circ} 33^{\prime} 36.12^{\prime \prime} \mathrm{E}$ & $7^{\circ} 8^{\prime} 41.92 " \mathrm{~S}$ \\
\hline 6 & & $107^{\circ} 33^{\prime} 36.84^{\prime \prime} \mathrm{E}$ & $7^{\circ} 8^{\prime} 54.96 " \mathrm{~S}$ \\
\hline 7 & & $107^{\circ} 33^{\prime} 53.36^{\prime \prime} \mathrm{E}$ & $7^{\circ} 9^{\prime} 29.32 " \mathrm{~S}$ \\
\hline 8 & Margamulya & $107^{\circ} 33^{\prime} 57.74^{\prime \prime} \mathrm{E}$ & $7^{\circ} 9^{\prime} 35.17 " \mathrm{~S}$ \\
\hline 9 & & $107^{\circ} 34^{\prime} 6.80^{\prime \prime} \mathrm{E}$ & $7^{\circ} 9^{\prime} 47.64 " \mathrm{~S}$ \\
\hline
\end{tabular}

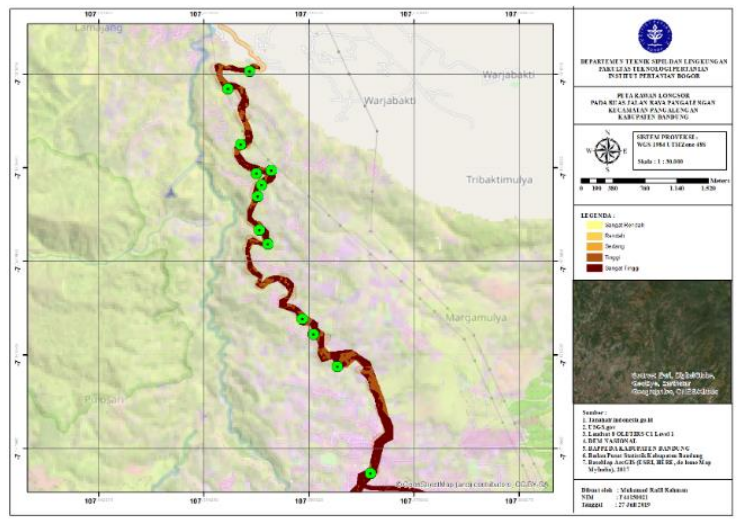

Gambar 10 Rekomendasi lokasi tindakan mitigasi bencana longsor

\section{KESIMPULAN}

Hasil analisis potensi rawan longsor di Kec. Pangalengan menggunakan DVMBG 2004 menunjukkan bahwa klasifikasi sangat tinggi memiliki persentase $97.24 \%$ dan hasil analisis menggunakan DVMBG 2005 memiliki persentase untuk klasifikasi tinggi sebesar
$44.42 \%$ dan klasifikasi sangat tinggi $53.26 \%$. Hasil analisis potensi rawan longsor pada ruas jalan raya Pangalengan memperoleh hasil untuk klasifikasi tinggi $44.267 \%$ dan klasifikasi sangat tinggi $55.70 \%$.

Hasil input data kejadian longsor 5 tahun terakhir di Kecamatan Pangalengan pada peta longsor Kecamatan Pangalengan menunjukkan bahwa rekam jejak longsor pada tahun 2015, 2018 dan 2019 berada pada klasifikasi sangat tinggi. Hal ini menunjukkan bahwa peta longsor yang dibuat sudah tervalidasi dan dapat digunakan sebagai acuan tindikan mitigasi bencana longsor. Terdapat 9 titik daerah yang berpotensi longsor pada ruas jalan raya Pangalengan, diantaranya 6 titik di Desa Tribaktimulya dan 3 titik di Desa Margamulya yang harus segera dilakukan tindakan mitigasi.

\section{DAFTAR PUSTKA}

Al-doski J, Shattri B, Mansor I, Shafri HZM. 2013. Image Classification in Remote Sensing. Journal of Environment and Earth Sciece. 3(10):141-147.

BPS] Badan pusat Statistik. 2017. Kecamatan Pangalengan dalam Angka 2017. Bandung (ID): BPS Bandung.

[BNPB] Badan Nasional Penanggulangan Bencana. 2015. Peta Bencana Tanah Longsor di Kecamatan Pangalengan, Kab. Bandung, Jawa Barat. Bandung (ID): Badan Nasional Penanggulangan Bencana. [DVMBG] Direktorat Vulkanologi dan Mitigasi Bencana Geologi. 2004. Manajemen Bencana Tanah Longsor. Bandung (ID): DVMBG. 
JSIL | Rahman dkk. : Analisis Kelongsaran Pada Ruas Jalan Raya Pangalengan Menggunakan Sistem Infarmasi Geografis

[DVMBG] Direktorat Vulkanologi dan Mitigasi Bencana Geologi. 2005. Manajemen Bencana Tanah Longsor. Bandung (ID): DVMBG.

Guzzeti F, Carddinali M, Reichenbach P, Cipolla F, Sebastiani C, Galli M, Salvati P. 2004. Landslides triggered by the 23 November 2000 rainfall event in the Imperia Province, Western Luguria, Italy. Engineering Geology. 73(3):229-245.

Hafidz, A., Fauzan, M., Putra, H., Santoso, A.D., 2019. Analisis Perubahan Faktor Keamanan Lereng Akibat Hujan. Jurnal Teknik Sipil dan Lingkungan. 4(3):169-176

Indrawahyuni $\mathrm{H}$, Munawir A, Damayanti I. 2009. Pengaruh variasi Kepadatan Pada Pemodelan Fisik menggunakan Tanah Berlempung Terhadap Stabilitas Lereng. Jurnal Teknik Sipil. 3(3):192-208.

Larsen MC dan Simon A. 1993. A Rainfall Intensity-Duration
Threshold for Landslides in A Humid-Tropical Environment, Puerto Rico. Geografisika Annaler. 7(55):13-23

[LPBI-NU] Lembaga Penanggulangan Bencana dan Perubahan Iklim Nahdatul Ulama. 2017. Penyusunan Peta Ancaman. Jakarta (ID): LPBINU.

PUSLITANAK.1997. Buku Penyusunan Kriteria Kesesuaian Lahan untuk Komoditas Pertanian. Bogor (ID): BPPP Departemen Pertanian Bogor.

Putra, H., Rifai'i, A., Sujono, J., Silarukmi, A., 2017. Analysis of Unsaturated Soil Parameters as Slope Stability Analysis. Jurnal Teknologi, 79(7-2): 21-27

Santosa, Suryadi, Heri, suprapto, Budi. 1998. Mekanika Tanah Lanjutan. Jakarta (ID): Gunadarma. 